\title{
STUDI TENTANG KINERJA PETUGAS REKAM MEDIS DI RUMAH SAKIT
}

\section{STUDY ON PERFORMANCE OF MEDICAL RECORD OFFICERS IN HOSPITAL}

\author{
Syamsuriansyah ${ }^{1}$ \\ Reni Chairunnisah ${ }^{2}$ \\ Helmina Andriani ${ }^{3}$ \\ Yan Reiza Permana 4 \\ Uswatun Hasanah ${ }^{5}$ \\ Jihadil Qudsi6 \\ Nik Azliza bt Nik Arifin ${ }^{7}$ \\ 1,2,3,4,5Program Studi Diploma Tiga Rekam Medis dan Informasi Kesehatan \\ 6 Politeknik Medica Farma Husada Mataram, NTB \\ 7 Faculty of Information Management Universiti Teknologi MARA, Selangor, Malaysia \\ E-mail:sammuma78@gmail.com
}

\begin{abstract}
Medical record is written evidence about the service process which contains patient clinical data during the process of diagnosis and treatment. The management of medical records in hospitals is to support the achievement of administrative order of the efforts to achieve hospital goals, improving the quality of health services in hospitals. The purpose of this study is to describe the performance of medical record data management officers in the storage room of the Hospital. This research method using descriptive method. The study population was all medical record officers with a sample of 11 respondents using census techniques. The analysis technique uses descriptive analysis. The results of the research on the educational level of the Hospital officers were part of the DIII Medical Records as many as 7 people (63.6\%). The minimum working period of the respondent is 1 year and the maximum is 9 years. The average working period of medical record officers at Hospital was 5.14 years. The results showed that the performance of medical record officers consisting of job quality, work quantity, attendance, supervision and conservation showed that there were 7 officers $(63.6 \%)$. have a good performance while as many as 4 medical record officers (36.4\%) have poor performance.
\end{abstract}

Key word: level of education, work length, performance

\begin{abstract}
Abstrak
Rekam medis merupakan salah satu bukti tertulis tentang proses pelayanan yang yang berisi tentang data klinis pasien selama proses diagnosis dan pengobatan. Pengelolaan rekam medis di rumah sakit adalah untuk menunjang tercapainya tertib administrasi dalam rangka upaya mencapai tujuan rumah sakit, yaitu peningkatan mutu pelayanan kesehatan di rumah sakit. Tujuan penelitian ini adalah Menggambarkan kinerja petugas pengelola data rekam medis di ruang penyimpanan Rumah Sakit. Metode penelitian ini menggunakan metode deskriptif. Populasi penelitian adalah seluruh petugas rekam medis dengan sampel berjumlah 11 responden dengan teknik sensus. Teknik analisis menggunakan analisis deskriptif. Hasil penelitian tingkat pendidikan petugas Rumah Sakit sebagian adalah DIII Rekam Medis sebanyak 7 orang $(63,6 \%)$. Minimal masa kerja responden adalah 1 tahun dan maksimal 9 tahun. Rata-rata masa kerja petugas rekam medis di Rumah Sakit adalah 5,14 tahun Hasil penelitian menunjukkan bahwa kinerja petugas rekam medis yang terdiri dari kualitas pekerjaan, kuantitas pekerjaan, kehadiran, supervisi dan konservasi diketahui bahwa sebanyak 7 petugas $(63,6 \%)$ mempunyai kinerja yang baik sedangkan sebanyak 4 petugas rekam medis $(36,4 \%)$ mempunyai kinerja yang kurang baik.
\end{abstract}

Kata kunci: Tingkat Pendidikan, Masa Kerja, Kinerja 


\section{A. PENDAHULUAN}

Rumah sakit merupakan sarana pelayanan kesehatan yang mutlak dibutuhkan oleh segenap lapisan masyarakat dalam upaya peningkatan derajat kesehatan baik individu maupun masyarakat secara keseluruhan. Untuk memenuhi kebutuhan tersebut maka rumah sakit dituntut untuk memberikan pelayanan yang memadai dan memuaskan. Oleh karena itu, rumah sakit harus mampu meningkatkan kualitas pelayanannya, termasuk diantaranya peningkatan kualitas pendokumentasian rekam medis (Pamungkas, dkk, 2010).

Menurut SK Men PAN

No.135/2002 dalam Kepmenkes No.377/Menkes/SK/III/2007, bahwa rekam medis adalah berkas yang berisi catatan dan dokumen tentang identitas pasien, pemeriksaan, pengobatan, tindakan dan pelayanan lain kepada pasien di sarana pelayanan kesehatan. Rekam medis bersifat rahasia karena menyangkut data pribadi seseorang dengan penyakit yang diderita, riwayat penyakit dan diagnosis lainnya. Mengingat begitu pentingnya isi serta peranan rekam medis, seharusnya setiap rumah sakit dan institusi pelayanan kesehatan menyimpan, menyusun dan merawat rekam medis dengan baik serta menjaga keamanannya dari kerusakan dan penyalahgunaan oleh pihak-pihak tertentu yang tidak berhak, dan juga menyediakan berkas rekam medis tersebut setiap kali dibutuhkan.

Pengelolaan rekam medis di rumah sakit adalah untuk menunjang tercapainya tertib administrasi dalam rangka upaya mencapai tujuan rumah sakit, yaitu peningkatan mutu pelayanan kesehatan di rumah sakit. Dalam pengelolaan rekam medis untuk menunjang mutu pelayanan bagi rumah sakit, pengelolaan rekam medis harus efektif dan efisien (Giyana, 2012).
Pada tanggal 15 April 2013 peneliti melakukan studi pendahuluan di Rumah Sakit. Data rekam medis dalam tiga tahun terakhir terdapat beberapa data rekam medis yang hilang dimana pada tahun 2010 jumlah data 48.329 pada tahun 2011 mengalami penurunan menjadi 48.285 dan pada tahun 2012 mengalami penurunan kembali menjadi 48.247. Berdasarkan hal tersebut diketahui bahwa jumlah data rekam medis mengalami penurunan dari tahun 2010 - 2012.

Fenomena yang ditemukan pada penelitian Rumah Sakit melaui obsevasi diketahui bahwa dari 11 karyawan rekam medis diketahui bahwa masih terdapat karyawan dengan tingkat pendidikan SMA sebanyak 4 orang. Survey lain menunjukkan bahwa rumah sakit ini memiliki jumlah pasien rawat inap yang besar, oleh karena itu semakin banyak pula jumlah berkas rekam medis yang harus dikelola. Salah satu pengelolaan yang masih menjadi kendala adalah pengisian berkas rekam medis pasien rawat inap yang terkadang tidak diisi oleh dokter. Permasalahan lain dalam proses pengolahan data adalah adanya kesulitan dalam pengolahan data, data yang tercecer atau pengarsipan data yang belum teratur, seperti halnya penumpukan data pasien, data poliklinik, data rawat inap. Selain itu data rekam medik yang tersimpan di rak-rak penyimpanan semakin hari semakin bertambah dan semakin menumpuk sehingga memakan tempat yang banyak. Banyaknya data rekam medik yang tersimpan terkadang salah penempatan pada tempatnya dan menimbulkan data rekam medik hilang atau rusak. Terkadang pegawai dapat melakukan kesalahan dalam mengolah data. Pada proses pencarian data adanya kesulitan dalam melakukan pencarian. 


\section{B. METODE PENELITIAN}

Jenis penelitian yang digunakan adalah deskriptif yang digunakan untuk mendeskripsikan. Populasi pada penelitian ini adalah petugas rekam medis Rumah Sakit sebanyak 11 orang. Teknik sampel dalam penelitian ini menggunakan teknik sensus.

Variabel dalam penelitian ini yaitu: Variabel bebas dalam penelitian ini adalah pengetahuan dan masa kerja. Variabel terikat dalam penelitian ini adalah kelengkapan pendokumentasian lembar partograf.

\section{HASIL DAN PEMBAHASAN}

\section{Hasil}

\section{Tingkat Pendidikan}

Hasil tingkat pendidikan petugas rekam medis pada Rumah Sakit adalah sebagai berikut :

Tabel 1. Tingkat Pendidikan Petugas Rekam Medis Rumah Sakit

\begin{tabular}{cllc}
\hline No & Pendidikan & N & $\%$ \\
\hline 1 & SMA & 4 & 36,4 \\
2 & D3 Rekam Medis & 7 & 63,6 \\
\hline Total & & 11 & 100 \\
\hline
\end{tabular}

Hasil tabel 1 menunjukkan bahwa petugas rekam medis di Rumah Sakit dengan tingkat pendidikan SMA sebanyak 4 orang $(36,4 \%)$ dan DIII Rekam Medis sebanyak 7 orang $(63,6 \%)$.

2. Masa Kerja

Hasil masa kerja petugas rekam medis pada Rumah Sakit adalah sebagai berikut :

Tabel 2. Masa Kerja Petugas Rekam Medis Rumah Sakit

\begin{tabular}{cccc}
\hline No & Masa Kerja (th) & N & $\%$ \\
\hline 1 & 1 & 1 & 9,1 \\
2 & 2 & 1 & 9,1 \\
3 & 3 & 1 & 9,1 \\
4 & 6 & 1 & 9,1 \\
5 & 7 & 3 & 27,3 \\
6 & 8 & 1 & 9,1 \\
7 & 9 & 3 & 27,3 \\
\hline Rata-rata & 5,14 & 11 & 100 \\
\hline
\end{tabular}

Hasil tabel 2 menunjukkan bahwa minimal masa kerja responden adalah 1 tahun dan maksimal 9 tahun. Rata-rata masa kerja petugas rekam medis di Rumah Sakit adalah 5,14 tahun. 


\section{Kinerja Petugas Rekam Medis}

Hasil penelitian menunjukkan bahwa kinerja petugas rekam medis dengan indikator kualitas pekerjaan, kuantitas pekerjaan, kehadiran, supervisi dan konservasi diketahui bahwa sebanyak 7 petugas $(63,6 \%)$ mempunyai kinerja yang baik sedangkan sebanyak 4 petugas $(36,4 \%)$ mempunyai kinerja yang kurang baik. Hal tersebut dapat dilihat dari masing-masing indikator sebagai berikut :

a. Kualitas Pekerjaan

Hasil wawancara dengan petugas rekam medis Rumah Sakit mengenai kualitas pekerjaan petugas rekam medis adalah sebagai berikut:Tabel 3. Kualitas Pekerjaan Petugas Rekam Medis

\begin{tabular}{llrrrr}
\hline \multirow{2}{*}{ No } & \multicolumn{1}{c}{ Pertanyaan } & \multicolumn{2}{c}{ Ya } & \multicolumn{2}{c}{ Tidak } \\
\cline { 2 - 6 } & $\mathrm{N}$ & $\%$ & $\mathrm{n}$ & $\%$ \\
\hline 1 & Konsentrasi dalam pekerjaan & 11 & 100 & 0 & 0.0 \\
2 & $\begin{array}{l}\text { Pekerjaan yang dilakukan selalu benar } \\
3\end{array}$ & 9 & 81.8 & 2 & 18.2 \\
& $\begin{array}{l}\text { Penampilan petugas selalu } \\
\text { berpenampilan rapi }\end{array}$ & 11 & 100 & 0 & 0.0 \\
$\begin{array}{l}\text { Hasil kerja sesuai dengan tugas } \\
\text { yang diberikan }\end{array}$ & 11 & 100 & 0 & 0.0 \\
\hline Rata-Rata & & 95,5 & & 4,5 \\
\hline
\end{tabular}

Hasil penelitian menunjukkan bahwa seluruh petugas rekam medis (100\%) menyatakan berkonsentrasi dalam pekerjaan, penampilan petugas rapi dan hasil kerja sesuai dengan tugas yang diberikan sedangkan 9 petugas rekam medis $(81,8 \%)$ menyatakan bahwa pekerjaan yang dilakukan selalu benar

b. Kuantitas Pekerjaan

Hasil wawancara dengan petugas rekam medis Rumah Sakit mengenai kuantitas pekerjaan petugas sebagai berikut :

Tabel 4. Kuantitas Pekerjaan Petugas Rekam Medis

\begin{tabular}{llcccc}
\hline \multirow{2}{*}{ No } & \multicolumn{1}{c}{ Pertanyaan } & \multicolumn{2}{c}{ Ya } & \multicolumn{2}{c}{ Tidak } \\
\cline { 3 - 6 } & Pekerjaan selalu selesai tepat waktu & $\%$ & $\mathrm{~N}$ & $\%$ \\
\hline 1 & Mampu menyelesaikan tugas & 8 & 72.7 & 3 & 27.3 \\
\hline 2 & $\begin{array}{l}\text { Inisiatif dalam melaksanakaan pekerjaan tanpa } \\
\text { perintah atasan }\end{array}$ & 11 & 100 & 0 & 0.0 \\
\hline 4 & $\begin{array}{l}\text { Bersedia bekerja lembur bila pekerjaan tidak } \\
\text { selesai tepat waktu }\end{array}$ & 8 & 72.7 & 3 & 27.3 \\
\hline Rata-rata & & 79.5 & 20.5 \\
\hline
\end{tabular}

Hasil penelitian menunjukkan bahwa seluruh petugas rekam medis (100\%) menyatakan berinisiatif dalam melaksanakan pekerjaan tanpa perintah atasan sedangkan 8 petugas rekam medis $(72,7 \%)$ menyatakan bahwa pekerjaan selalu selesai tepat waktu, mampu menyelesaikan tugas dengan alokasi waktu yang telah ditetapkan dan bersedia bekerja lembur. 
c. Supervisi Petugas Rekam Medis

Hasil wawancara dengan petugas rekam medis Rumah Sakit mengenai supervisi adalah sebagai berikut :

Tabel 5. Supervisi Petugas Rekam Medis

\begin{tabular}{|c|c|c|c|c|c|}
\hline \multirow[t]{2}{*}{ No } & \multirow[t]{2}{*}{ Pertanyaan } & \multicolumn{2}{|c|}{ Ya } & \multicolumn{2}{|c|}{ Tidak } \\
\hline & & $\mathrm{N}$ & $\%$ & $\mathrm{~N}$ & $\%$ \\
\hline 1 & $\begin{array}{l}\text { Pimpinan selalu melakukan pengawasan pada } \\
\text { pekerjaan }\end{array}$ & 5 & 45.5 & 6 & 54.5 \\
\hline 2 & $\begin{array}{l}\text { Pimpinan selalu memberikan arahan dalam } \\
\text { setiap pekerjaan }\end{array}$ & 5 & 45.5 & 6 & 54.5 \\
\hline 3 & Pimpinan selalu melakukan evaluasi pekerjaan & 11 & 100 & 0 & 0.0 \\
\hline Rat & rata & & 63.6 & & 54.5 \\
\hline
\end{tabular}

Hasil penelitian menunjukkan bahwa seluruh petugas rekam medis (100\%) menyatakan bahwa pimpinan selalu melakukan evaluasi pekerjaan sedangkan 6 petugas rekam medis $(54,4 \%)$ menyatakan bahwa pimpinan tidak selalu melakukan pengawasan dan tidak selalu memberikan arahan dalam setiap pekerjaan.

d. Kehadiran

Hasil wawancara dengan petugas rekam medis Rumah Sakit mengenai kehadiran adalah sebagai berikut:

Tabel 6. Kehadiran Petugas Rekam Medis

\begin{tabular}{|c|c|c|c|c|c|}
\hline \multirow[t]{2}{*}{ No } & \multirow[t]{2}{*}{ Pertanyaan } & \multicolumn{2}{|c|}{ Ya } & \multicolumn{2}{|c|}{ Tidak } \\
\hline & & $\mathrm{N}$ & $\%$ & $\mathrm{~N}$ & $\%$ \\
\hline 1 & Kehadiran selalu tepat waktu & 11 & 100 & 0 & 0 \\
\hline 2 & Pulang kerja selalu tepat waktu & 4 & 36.4 & 7 & 63.6 \\
\hline Ratá & rata & & 68.2 & & 63.6 \\
\hline
\end{tabular}

Hasil penelitian menunjukkan bahwa seluruh petugas rekam medis (100\%) menyatakan bahwa kehadirannya selalu tepat waktu sedangkan 7 petugas rekam medis $(63,6 \%)$ menyatakan bahwa terkadang pulang kerja tidak tepat waktu karena harus menyelesaikan pekerjaan secara lembur.

e. Konservasi Petugas Rekam Medis

Hasil wawancara dengan petugas rekam medis Rumah Sakit mengenai konservasi adalah sebagai berikut :

Tabel 7. Konservasi Petugas Rekam Medis

\begin{tabular}{llcccc}
\hline \multirow{2}{*}{ No } & \multicolumn{3}{c}{ Pertanyaan } & \multicolumn{2}{c}{ Tidak } \\
\cline { 3 - 6 } & M & $\%$ & $\mathrm{~N}$ & $\%$ \\
\hline 1 & $\begin{array}{l}\text { Mahir menggunakan computer dalam } \\
\text { pengelolaan data }\end{array}$ & 11 & 100 & 0 & 0 \\
\hline 2 & Melakukan perawatan peralatan setiap hari & 4 & 36.4 & 7 & 63.6 \\
\hline Rata-rata & & 68.2 & & 63.6 \\
\hline
\end{tabular}

Hasil penelitian menunjukkan bahwa seluruh petugas rekam medis (100\%) menyatakan bahwa petugas mahir dalam menggunakan komputer dalam pengelolaan data sedangkan Hasil penelitian menunjukkan bahwa sebanyak 3 orang $(27,3 \%)$ menyatakan bahwa petugas melakukan perawatan peralatan setiap hari sedangkan 7 petugas rekam medis $(63,6)$ menyatakan bahwa petugas tidaselalu melakukan perawatan setiap harinya karena peralatan komputer masih dapat digunakan dengan baik, sedangkan peralatan-peralatan lain seperti filling kabinet, rak dan lain-lain setiap hari memang dibersihkan dan dirapikan. 


\section{Pembahasan}

Hasil penelitian menunjukkan bahwa kinerja petugas rekam medis dengan indikator kualitas pekerjaan, kuantitas pekerjaan, kehadiran, supervisi dan konservasi diketahui bahwa sebanyak 7 petugas $(63,6 \%)$ mempunyai kinerja yang baik sedangkan sebanyak 4 petugas rekam medis (36,4\%) mempunyai kinerja yang kurang baik.

Kinerja organisasi akan sangat ditentukan oleh unsur pegawainya karena itu dalam mengukur kinerja suatu organisasi sebaiknya diukur dalam tampilan kerja dari pegawainya. Pengertian kinerja menurut Mangkunegara (2006) adalah hasil kerja secara kualitas dan kuantitas yang dicapai oleh seorang pegawai dalam melaksanakan tugasnya sesuai dengan tanggung jawab yang diberikan kepadanya.

Hasil penelitian menunjukkan bahwa sebagian besar petugas rekam medis mempunyai tingkat pendidikan DIII Rekam medis dan hal ini sesuai dengan bidang tugasnya saat ini. Kinerja petugas rekam medis dipengaruhi oleh tingkat pendidikan responden. Hal ini sesuai dengan pernyataan dari Lewa dan Subowo (2005) bahwa pendidikan merupakan faktor internal atau faktor dari dalam diri karyawan yang dapat mempengaruhi kinerja. Hal ini juga diperkuat oleh pernyataan Ravianto (2008) bahwa salah satu faktor yang dapat mempengaruhi kinerja adalah latar belakang pendidikan.

Hasil penelitian menunjukkan bahwa masa kerja petugas rekam medis rata-rata adalah selama 5,14 tahun, masa kerja petugas rekam medis dalam bekerja ini dipengaruhi oleh beberapa hal antara lain adalah lingkungan kerja yang menyenangkan dan adanya kerjasama yang baik antar karyawan. Masa kerja dari petugas rekam medis ini berpengaruh terhadap kinerja karyawan. Hal ini sesuai dengan pernyataan dari Lewa dan Subowo (2005) yang menyatakan bahwa salah satu faktor internal yang mempengaruhi kinerja karyawan adalah pengalaman kerja.

Kinerja petugas Rekam Medis didasarkan pada uraian tugas pokok dan fungsinya sebagai petugas rekam medis baik di bagian pendaftaran, pengkodean, pendistribusian dan analisis data berkas rekam medik. Pelaksaaan tugas pokok dan fungsi dalam suatu organisasi tergantung pada pendidikan, pengetahuannya, kejelasan uraian tugasnya, serta faktor pengalamannya. Hal ini relevan dengan pendapat Suprihanto (2006), kinerja (performance) adalah hasil kerja yang dapat dicapai oleh seseorang atau sekelompok orang dalam suatu organisasi, sesuai dengan wewenang dan tanggung jawab masingmasing dalam rangka upaya mencapai tujuan organisasi secara legal, tidak melanggar hukum dan sesuai dengan moral dan etika

Suprihanto (2006) juga menyatakan bahwa dalam penilaian kinerja umumnya hanya menilai hasil fisik, tetapi pelaksanaan pekerjaan perlu dipertimbangkan secara keseluruhan karena menyangkut berbagai bidang seperti kemampuan kerja, kerajinan, disiplin, hubungan kerja atau hal-hal khusus sesuai dengan bidang dan tingkat pekerjaan yang dijabatnya dimana ada 5 (lima) faktor dalam penilaian kinerja antara lain adalah kualitas pekerjaan, meliputi : akurasi, ketelitian, penampilan, dan penerimaan keluaran, kuantitas pekerjaan, meliputi : volume keluaran dan kontribusi, supervisi, meliputi : membutuhkan saran, arahan, atau perbaikan, kehadiran, meliputi : reguralitas, dapat dipercayai/andalkan, dan ketepatan waktu dan konservasi, meliputi : pencegahan pemborosan, kerusakan, pemeliharaan peralatan.

Seorang pegawai yang dinilai menunjukan kemungkinan tidak berkinerja dengan baik akan tetapi sebenarnya dia mempunyai potensi, bisa jadi lingkungan kerjanya yang tidak 
mendukung. Sedangkan pendapat lain menyatakan, ada beberapa faktor yang mempengaruhi kinerja : 1) Faktor personal/individual, meliputi: pengetahuan, keterampilan (skill), kenampuan, kepercayaan diri, motivasi, dan komitmen yang dimiliki oleh setiap individu; 2) Faktor kepemimpinan, meliputi: kualitas dalam memberikan dorongan, semangat, arahan, dan dukungan yang diberikan manajer dan team leader; 3) Faktor tim, meliputi: kualitas dukungan dan semangat yang diberikan oleh rekan dalam satu tim, kepercayaan terhadap sesama anggota tim, kelompokan dan keeratan anggota tim; 4) Faktor sistem, meliputi: sistem kerja, fasilitas kerja atau infrastruktur yang diberikan oleh organisasi, proses organisasi, dan kultur kinerja dalam organisasi dan 5) Faktor kontekstual (situasional), meliputi: tekanan dan perubahan lingkungan eksternal dan internal (Mahmudi, 2005:21)

\section{SIMPULAN DAN SARAN}

\section{Simpulan}

Simpulan dari hasil penelitian ini adalah sebagai berikut :

1. Tingkat pendidikan petugas Rumah Sakit sebagian adalah DIII Rekam Medis sebanyak 7 orang $(63,6 \%)$.

2. Masa kerja petugas rekam medis di Rumah Sakit rata-rata adalah 5,14 tahun.

3. Hasil penelitian menunjukkan bahwa kinerja petugas rekam medis yang terdiri dari kualitas pekerjaan, kuantitas pekerjaan, kehadiran, supervisi dan konservasi diketahui bahwa sebanyak 7 petugas $(63,6 \%)$ mempunyai kinerja yang baik sedangkan sebanyak 4 petugas $(36,4 \%)$ mempunyai kinerja yang kurang baik.

\section{Saran}

Saran yang dapat diberikan adalah sebagai berikut :

1. Bagi petugas rekam medis diharapkan dapat mengikuti pelatihan misalnya seminar yang diadakan oleh rumah sakit untuk dapat meningkatkan pengalamannya sehingga seiring dengan masa kerja karyawan maka kemampuan kerja karyawan semakin baik dan kinerjanya juga mengalami peningkatan.

2. Bagi rumah sakit, hendaknya melakukan pembagian shift di mana selama ini petugas rekam medis yang bekerja di pagi hari jumlahnya lebih banyak daripada yang malam hari, sehingga dengan pembagian shift yang baik, maka jumlah petugas baik pagi maupun malam jumlahnya seimbang.

3. Bagi peneliti selanjutnya diharapkan agar meningkatkan kualitas penelitian lebih lanjut khususnya yang berkaitan dengan kinerja petugas rekam medis.

\section{E. DAFTAR PUSTAKA}

Kepmenkes RI. 2007. Keputusan Menteri Kesehatan Republik Indonesia Nomor 377 Tahun 2007 Tentang Standar Profesi Perekam Medis Dan Informasi Kesehatan. Diakses dari: www.depkes.go.id tanggal 13 Maret 2013.

Lewa, K., Iip, Idham, Eka dan Subowo. 2005. Pengaruh Kepemimpinan, Lingkungan Kerja Fisik dan Kompensasi Terhadap Kinerja Karyawan di PT. Pertamina (Persero) Daerah Operasi Hulu Jawa Bagian Barat Cirebon. Jurnal Sinergi: Kajian Bisnis dan Manajemen Edisi Khusus on Human Resources 
Mangkunegara, AP. Manajemen Sumber Daya Manusia. Bandung: Remaja Rosdakarya

Rivai, V. 2005. Manajemen Sumber Daya Manusia Untuk Perusahaan: Dari Teori Ke Praktik. Jakarta: PT. Raja Grafindo Persada

Suprihanto J. 2006. Perilaku Organisasional. Yogyakarta: Sekolah Tinggi Ilmu Ekonomi YKPN 